\title{
Evidence of hybridization between two species of Melipona bees
}

\author{
Vania Alves Nascimento, Syomara Hakiko Matusita and Warwick Estevam Kerr
}

\begin{abstract}
This report describes a case of hybridization between two species of Meliponinae bees (Melipona scutellaris from the Diamantina plateau in the State of Bahia, and Melipona capixaba from around Domingos Martins, in the State of Espírito Santo, Brazil). To demonstrate hybridization, electrophoretic profiles of esterase activity from three colonies were studied. Ten adult workers of $M$. scutellaris, $M$. capixaba and the hybrid colony were collected and processed individually. The pattern of esterase activity was constant for each species but differed between them, whereas hybrid bees had a pattern derived from both species. The fact that two ecologically different species of stingless bees separated by more than $300 \mathrm{~km}$ could still cross when placed in the same area suggests that there has not been any pressure to develop reproductive isolation.
\end{abstract}

\section{INTRODUCTION}

The greatest diversity of the Meliponinae occurs in the Neotropical region, where there are more than 300 described species (Camargo and Pedro, 1992). Meliponine bees have a fundamental role in perpetuating the ecosystems where they occur in Brazil since they are responsible for pollinating 40 to $90 \%$ of the native flora (Kerr et al., 1994). Melipona (Michmelia) capixaba is endemic to the Atlantic forest, where it is restricted to the mountainous area of Espírito Santo State. In 1995, five colonies of M. capixaba were transferred to the meliponary in Uberlândia, MG, Brazil. After five months, one of the colonies began producing workers that were morphologically different from the others of its species. In these altered workers, the abdomen, which is generally brilliant black, showed white stripes similar to those found in M. scutellaris.

In insects, esterases catalyze the hydrolysis of ester bonds and have been shown to participate in digestive processes, in the regulation of juvenile hormone production and in the degradation of insecticides. Sheppard and Berlocher (1989) used enzymatic systems to demonstrate the existence of inter-specific and intra-specific variation in four species of Apis. Scarpassa et al. (1996) studied the profile of esterases in six populations of Anopheles nuneztovari and observed that the enzymes at locus EST5 had high levels of allelic variability among Brazilian populations but low variability among Colombian populations. Del Lama et al. (1990) examined seven loci for isoenzymes in adult workers of Apis mellifera, three of which showed polymorphism that allowed genetic differentiation among populations of Africanized bees in Brazil and Central America.

Endler (1998) defined natural hybridization as a pro- cess in which crosses occur naturally among two or more populations, with the progeny being distinguished on the basis of one or more inherited characters. In this study, we used esterase profiles to examine the hybridization between species of Melipona (Melipona scutellaris from the Diamantina Plateau in the State of Bahia and M. capixaba from the county of Domingos Martins in the State of Espírito Santo, Brazil). These species are separated from each other by a distance of more than $300 \mathrm{~km}$.

\section{MATERIAL AND METHODS}

Ten adult workers of $M$. scutellaris, M. capixaba and 10 workers from the colony suspected of hybridization were collected in our meliponary in Uberlândia and stored at $-70^{\circ} \mathrm{C}$. The bees were macerated individually with a glass rod in Eppendorf tubes, in the presence of $80 \mu \mathrm{l}$ of Tris- $\mathrm{HCl}$ buffer $(0.1 \mathrm{M}, \mathrm{pH} 8.8)$. After centrifugation to $11,600 \mathrm{~g}(10 \mathrm{~min})$ a $20-\mu \mathrm{l}$ aliquot of the supernatant was removed and mixed with $20 \mu \mathrm{l}$ of Tris-HCl buffer $(0.1 \mathrm{M}$, $\mathrm{pH}$ 8.8). After a further centrifugation $(11,600 \mathrm{~g}$ to 10 $\mathrm{min}), 10-\mu \mathrm{l}$ of supernatant was applied to $10 \%$ polyacrylamide gels with Tris-glycine $(0.0125 \mathrm{M}$ of Tris, 0.096 $\mathrm{M}$ glycine, $\mathrm{pH}$ 8.3) as a buffer system and run under nondenaturing conditions at a constant current of $20 \mathrm{~mA}$ for $3.5 \mathrm{~h}$ at room temperature. Naphthol ester ( $\alpha$ and $\beta$ naphthol propionate) was used as substrate for the esterases. Enzymatic activity was detected using a freshly prepared solution consisting of $10 \mathrm{mg} \alpha$-naphthyl propionate and $10 \mathrm{mg}$ of $\beta$-naphthyl propionate dissolved in $1 \mathrm{ml}$ of acetone and mixed with $30 \mathrm{ml}$ of phosphate buffer $(0.1 \mathrm{M}$, $\mathrm{pH}$ 6.2), $3 \mathrm{ml}$ of methanol and $36 \mathrm{mg}$ of Fast Blue RR salt. The reaction was allowed to proceed for $45 \mathrm{~min}$ protected from light. At the end of this incubation, the reaction was 
stopped by placing the gel in a solution (ethanol:acetic acid:water, 5:1:5 v/v; Steiner and Johnson, 1973) for 24 $\mathrm{h}$. The gels were subsequently dried on cellophane paper at room temperature.

\section{RESULTS AND DISCUSSION}

Figure 1 shows that there were important differences between the esterase profiles of the two species. The hybrid colony showed same bands from each of the two species, confirming the suspicion of natural hybridization between $M$. capixaba and M. scutellaris, that was initially suggested by the external morphology.

M. scutellaris and M. capixaba showed seven bands of esterase activity each, with each species having four bands not present in the other; the hybrid showed a mixture of bands from the two species.

In their natural habitats, $M$. scutellaris is separated from M. capixaba by more than $300 \mathrm{~km}$ of forest. Although hybridization between different species can oc- cur in special conditions, in nature such gene exchange does not take place. The case of M. capixaba and M. scutellaris indicates that the geographical separation was abrupt, therefore with no pressure to build a sexual isolating mechanism.

Morphological characteristics such as the presence of yellow markings on the clipeus and inferior paraoculars and the structure of the genitalia are practically identical in the two species (Moure and Camargo, 1994). Rocha and Pompolo (1995) placed M. capixaba and M. scutellaris in the same karyotype group, characterized by a high heterochromatic content and euchromatin that is restricted to the extremities.

The esterase profiles of M. capixaba, M. scutellaris and the hybrid showed that the latter had bands common to both species. The lack of anatomical or behavioral isolation mechanisms allowed the crossing of these species when they were brought into the same area. These observations suggest that the two species are genetically similar and capable of forming fertile hybrids.

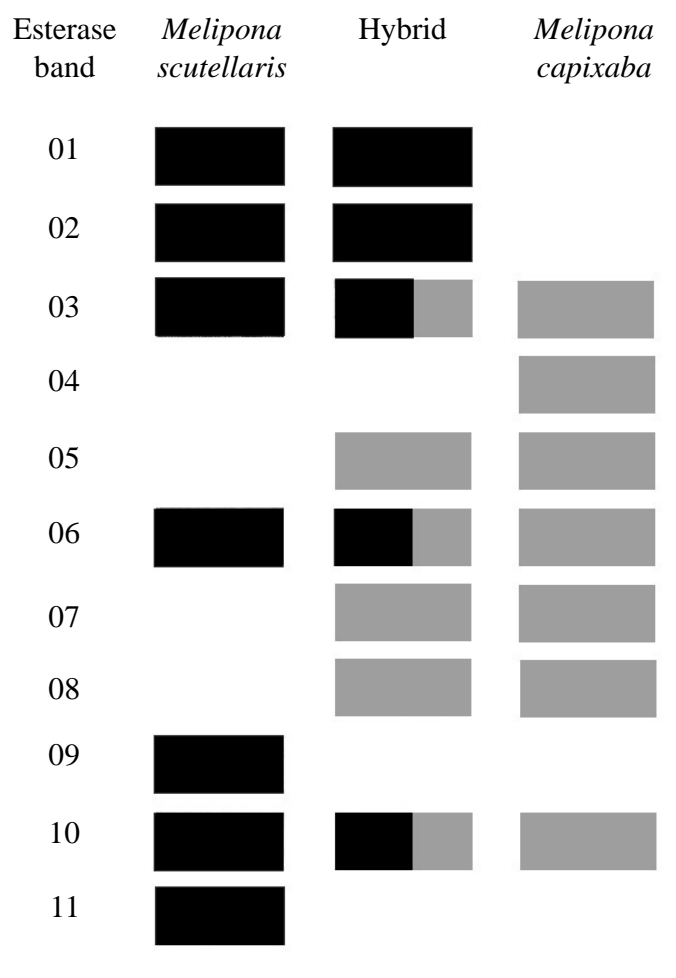

Legend:

Esterases of $M$. scutellaris

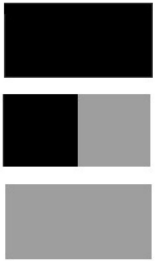

Esterases of hybrid

Esterases of M. capixaba

Figure 1 - Profile of esterase activity in M. scutellaris, M. capixaba and hybrid individuals. A total of 10 individuals were examined in each case. 


\section{ACKNOWLEDGMENTS}

The authors thank Reginaldo Pizzol and Alvino Pianzoli Filho who served as our guides in the county of Domingos Martins. V.A.N. and S.H.M. were the recipients of studentships from CAPES. This research was supported by the Banco do Brasil Research Foundation and by CNPq (Brazilian Research Council).

\section{RESUMO}

Este trabalho descreve um caso de hibridação entre duas espécies de meliponínios (Melipona scutellaris originária da Chapada Diamantina, Bahia, e Melipona capixaba oriunda da região de Domingos Martins, ES). Para demonstrar a hibridação, perfis eletroforéticos de esterases das três colônias foram estudados. Dez operárias adultas de colônias de M. scutellaris, M. capixaba e da colônia híbrida foram coletadas e processadas individualmente. O padrão de atividade esterásica foi constante para cada espécie, mas diferente entre elas, enquanto que os indivíduos da colônia híbrida apresentaram um padrão de atividade esterásica derivado de ambas as espécies. O fato de duas espécies de abelhas ecologicamente diferentes, separadas por mais de $300 \mathrm{~km}$, ainda poderem se cruzar quando colocadas em mesma área sugere que houve uma separação geográfica abrupta, sem ocorrência de pressão para desenvolvimento de isolamento reprodutivo.

\section{REFERENCES}

Camargo, J.M.F. and Pedro, S.R.M. (1992). Systematic, phylogeny and biogeography of the Meliponinae (Hymenoptera, Apidae): a mini-review. Apidologie 23: 509-522.

Del Lama, M.A., Lobo, J.A., Soares, A.E.E. and Del Lama, S.N. (1990), Genetic differentiation estimated by isozymic analysis of Africanized honeybee populations from Brazil and from Central America. Apidologie 21: 271-280.

Endler, J.A. (1998). The place of hybridization in evolution. Evolution 52 : 640-644.

Kerr, W. E., Nascimento, V.A. and Carvalho, G.A. (1994). Há salvação para os meliponínios? Anais do $1^{\circ}$ Encontro sobre Abelhas de Ribeirão Preto, Ribeirão Preto, SP, pp. 60-65.

Moure, J.S. and Camargo, J.M.F. (1994). Melipona (Michmelia) capixaba, uma nova espécie de Meliponinae (Hymenoptera, Apidae) do Sudeste do Brasil. Rev. Bras. Zool. 11: 289-296.

Rocha, M.P. and Pompolo, S.G. (1995). Conteúdo e distribuição de heterocromatina em oito espécies de abelhas do gênero Melipona (Apidae, Hymenoptera). Rev. Bras. Genet. 18 (Suppl.): 446.

Scarpassa, V.M., Tadei, W.P. and Suarez, M.F. (1996). Allozyme differentiation among allopatric populations of Anopheles nuneztovari (Diptera: Culicidae). Braz. J. Genet. 19: 256-269.

Sheppard, W.S. and Berlocher, S.H. (1989). Allozyme variation and differentiation among four Apis species. Apidologie 20: 419-431.

Steiner, W.W.M. and Johnson, W.E. (1973). Techniques for electrophoresis of Hawaiian Drosophila. US International Biological Program. Island Ecosystems IRP. Tech. Report 30: 1-21.

(Received September 22, 1998) 
